Artikel Penelitian

\title{
Kompetensi dan Kinerja Petugas First Line Badan Penanggulangan Bencana Provinsi Sulawesi Barat
}

\author{
Edi Purnomo, Zulhaini Sartika A. Pulungan
}

\begin{abstract}
Abstrak
Provinsi Sulawesi Barat adalah salah satu daerah rawan bencana karena berada dalam jalur tektonik cincin api dunia. Wilayah ini memiliki kerentanan tinggi terhadap kemungkinan terjadinya bencana alam geologi, seperti gempa bumi tektonik, gerakan tanah atau tanah longsor maupun banjir. Pelatihan kompetensi petugas first line Badan Penanggulangan Bencana sangat diperlukan untuk peningkatan kompetensi dan kinerja petugas sehingga dapat melakukan pertolongan pada saat terjadi bencana dengan cepat dan tepat. Tujuan penelitian ini adalah menentukan kompetensi dan kinerja petugas first line setelah dilakukan pelatihan pertolongan pertama saat terjadi bencana. Penelitian ini merupakan quasi eksperiment dengan rancangan one group pre-post test design. Subjek penelitian diambil secara purposive sampling sebanyak 33 orang. Data dianalisa menggunakan paired t-test. Hasil penelitian menunjukkan peningkatan kompetensi $(p=0,005)$ dan kinerja $(p=0,005)$ petugas first line Badan Penanggulangan Bencana Daerah Provinsi Sulawesi Barat setelah dilakukan pelatihan. Disarankan untuk mencapai optimalisasi kinerja petugas first line perlu dilaksanakan simulasi atau latihan bersama dan seminar penanggulangan bencana terpadu setiap semester.
\end{abstract}

Kata kunci: kompetensi, kinerja, petugas first line, BPBD

\section{Abstract}

West Sulawesi Province is one of the disaster prone areas because it is in the ring of fire tectonic belts of the world. This region has a high vulnerability to natural disasters geological possibilities, either a tectonic earthquake, ground movement or landslides and flooding. Competence training for first line officers Disaster Management Agency is indispensable for improving the competence and performance of staff so that it can help in times of disasters quickly and appropriately. The objective of this study was to determine the competence and performance of staff for first line after the first aid training when a disaster occurs. This research was a quasi experimental design with one group prepost test design. Subjects were taken by purposive sampling as many as 33 people. Data were analyzed using paired $t$-test. The results showed increased competence $(p=0.005)$ and performance $(p=0.005)$ for first line officers of the Regional Disaster Management Agency of West Sulawesi Province after the training. It is advisable to reach the optimal performance for first line officers need to be implemented simulations or exercises joint and integrated disaster management seminar each semester.

Keywords: competence, performance, first line personnel, BPBD

Affiliasi penulis: Jurusan Keperawatan Poltekkes Kemenkes Mamuju Korespondensi:: Edi Purnomo, Email:edi_purnomo7799@yahoo.com Telp. 081232324563

\section{PENDAHULUAN}

Badan Nasional Penanggulangan Bencana

(BNPB) mencatat 2.342 bencana terjadi sepanjang tahun 2016. Data BNPB menyebutkan kejadian bencana tahun ini merupakan tertinggi sejak kurun waktu 14 tahun terakhir. Kejadian bencana meningkat $35 \%$ dibandingkan tahun 2015. Dampak yang ditimbulkan bencana selama 2015 cukup besar. Bencana menyebabkan 522 jiwa meninggal, 3,05 juta 
jiwa menderita dan mengungsi, sekitar 70 ribu rumah rusak dan kerugian ekonomi mecapai puluhan trilyun rupiah. ${ }^{1}$

Provinsi Sulawesi Barat adalah salah satu daerah rawan bencana karena berada dalam jalur tektonik cincin api dunia. Wilayah ini memiliki kerentanan tinggi terhadap kemungkinan terjadinya bencana alam geologi, baik berupa gempa bumi tektonik, gerakan tanah atau tanah longsor maupun banjir. $^{2}$ Berdasarkan kondisi geologi wilayah, jenis tanah dan kondisi fisik lingkungan, maka Sulawesi Barat mempunyai potensi kerawanan bencana, baik yang disebabkan oleh alam maupun akibat dari pembangunan. Sulawesi Barat juga merupakan daerah yang rawan banjir, hal ini disebabkan karena lima dari enam kabupaten yang ada di Sulawesi Barat berada pada daerah pesisir pantai. Selain bahaya banjir, juga berpotensi bahaya tsunami khususnya di Kabupaten Mamuju, Majene dan Polewali Mandar dengan kategori run-up 2-5 (berbahaya) seperti yang pernah terjadi di Nangroe Aceh Darussalam. Kondisi wilayah Provinsi Sulawesi Barat yang meliputi daerah pengunungan dan dilintasi oleh sungai besar dan kecil sangat rawan terhadap bencana banjir khususnya banjir bandang akibat meluapnya aliran sungai. ${ }^{3}$

Beberapa bencana alam yang pernah dilaporkan terjadi antara lain: Banjir bandang di Kel. Sinyonyoi Kec. Kalukku Kab. Mamuju tahun 2008, yang mengakibatkan 1 orang meninggal dunia, 50 kepala keluarga mengungsi. Gempa bumi dengan kekuatan 5,3 SR berpusat di Mamuju Utara tahun 2010 yang mengakibatkan 1 orang meninggal dunia, 54 orang luka-luka dan 114 rumah rusak. Tanah longsor di jalur perlintasan Majene-Mamuju tahun 2012, mengakibatkan 1 orang meninggal dunia dan 10 orang mengalami luka-luka. Kejadian banjir di Kec. Mamuju dan Kec. Simboro, Kota Mamuju tahun 2014, mengakibatkan robohnya 3 unit rumah penduduk. Kejadian banjir di Kab. Mamuju, Mamuju Utara dan Mamuju Tengah tahun 2015, mengakibatkan 137 keluarga mengungsi; tanah longsor di Kab. Majene dan Mamasa; juga gempa bumi di Kab. Mamuju walaupun tidak mengakibatkan korban jiwa. ${ }^{2,4}$

Peningkatan frekuensi kebencanaan di Provinsi Sulawesi Barat saat ini, menunjukkan betapa rawan wilayah provinsi ini terhadap bencana banjir dan tanah longsor. Hal ini mengharuskan pemerintah beserta seluruh elemen masyarakatnya perlu lebih mewaspadai fenomena alam tersebut. Usaha pencegahan bencana banjir dan longsor terus dilakukan untuk mengurangi resiko yang ditimbulkannya, namun masyarakat belum sepenuhnya menyadari tindakan pencegahannya, terutama pada masyarakat yang tinggal dipemukiman rawan bencana banjir dan longsor. Bencana banjir dan tanah longsor dipengaruhi oleh dinamika atmosfer, hal ini ditunjukkan oleh perubahan iklim dan curah hujan yang sangat cepat dengan intensitas yang cukup ekstrem sehingga mengakibatkan kemampuan tanah dalam menyerap air tidak mampu mengimbangi jumlah air yang diterimanya. Selain itu juga dipengaruhi penebangan pohon di daerah hulu yang akhirnya menimbulkan bencana banjir tersebut.$^{2,4}$

BNPB dan BPBD provinsi maupun kabupaten di Sulawesi Barat sangat intensif dalam menanggulangi bencana, sebab dukungan pemerintah sangat penting dalam melaksanakan kegiatan penanggulangan bencana agar berjalan dengan baik. Pelibatan pihak swasta dan masyarakat harus dilakukan sebab dengan semakin majunya Provinsi Sulawesi Barat akan memicu banyaknya aktivitas masyarakat yang menyebabkan terjadinya bencana. Kesiapan daerah dalam menghadapi ancaman bencana harus direncanakan dan harus dibuat bersama-sama oleh seluruh stakeholder dan multisektor untuk menginventarisir tugas dan posisinya saat terjadi bencana. ${ }^{2}$

Berbagai program kesiapsiagaan dalam menghadapi bencana harus dilaksanakan oleh seluruh komponen pemerintah, masyarakat dan dunia usaha. Diantara program tersebut adalah pelatihan kompetensi petugas first line Badan Penanggulangan Bencana Daerah. Tim ini bertugas melaksanakan kegiatan kaji cepat bencana dan dampak bencana pada saat tanggap darurat, meliputi penilaian kebutuhan, penilaian kerusakan dan kerugian dalam penanggulangan bencana (2). Petugas first line merupakan jabatan fungsional dalam struktur organisasi BPBD Prov. Sulawesi Barat yang ternyata berasal dari latar belakang pendidikan yang berbeda- 
beda. Melihat pentingnya tugas tersebut diperlukan suatu kompetensi yang sama sehingga dapat menjalankan tugasnya dengan baik.

Kompetensi adalah seperangkat tindakan cerdas dan penuh tanggung jawab yang dimiliki seseorang sebagai syarat untuk dianggap mampu oleh masyarakat dalam melaksanakan tugas di bidang pekerjaan tertentu. ${ }^{5}$ Kompetensi mencakup gabungan pengetahuan, keterampilan dan sikap dalam menyelesaikan suatu pekerjaan sesuai dengan unjuk kerja yang ditetapkan. Petugas first line penanggulangan bencana wajib mengikuti pelatihan/pendidikan sehingga menghasilkan lulusan dengan kualifikasi minimalnya sesuai dengan Standar Kompetensi Kerja Nasional Indonesia (KKNI). ${ }^{6}$

Kompetensi yang harus dimiliki petugas first line salah satunya adalah melakukan pertolongan pertama. Unit kompetensi ini menjelaskan keterampilan, pengetahuan dan sikap yang diperlukan untuk memberikan tindakan pertolongan pertama, membantu kehidupan, mengelola korban, insiden dan penolong lainnya sampai datangnya bantuan medis. Elemen kompetensi yang dinilai adalah melakukan kajian situasi, menerapkan prosedur pertolongan pertama, mengkomunikasikan rincian insiden, dan mengevaluasi hasil kerja. $^{7}$ Kinerja sumber daya manusia merupakan istilah dari kata job performance atau actual performance (prestasi kerja) adalah hasil kerja secara kualitas dan kuantitas yang dicapai oleh seorang karyawan atau pegawai dalam melaksanakan tugasnya sesuai dengan tanggung jawab yang diberikan kepadanya. ${ }^{8}$

Berdasarkan data awal dari BPBD Prov. Sulawesi Barat, petugas first line penanggulangan bencana terdapat 12 orang berpendidikan SMA, 14 orang diploma tiga dan 7 orang sarjana dari berbagai disiplin ilmu. Hal ini memungkinkan kompetensi yang dimiliki oleh setiap orang petugas berbeda, sehingga penulis tertarik untuk melakukan pelatihan kompetensi untuk dapat meningkatkan kinerja petugas first line penanggulangan bencana di Prov. Sulawesi Barat.

\section{METODE}

Penelitian ini merupakan penelitian quasi eksperiment dengan rancangan one group pre-post test design. Subjek penelitian diambil secara purposive sampling setelah diberikan informed consent dan memenuhi kriteria inklusi antara lain terdaftar sebagai petugas garis pertama (first line) Badan Penanggulangan Bencana Prov. Sulawesi Barat, mengikuti pelatihan kompetensi sesuai jadual yang ditentukan. Subjek penelitian berjumlah 33 orang.

Variabel bebas dalam penelitian ini adalah pelatihan. Metode pelatihan yang digunakan adalah pengajaran dan simulasi. Pengajaran dilakukan dengan metode cepat dan sederhana untuk memberikan pengetahuan tentang bantuan hidup dasar kepada petugas first line. Simulasi dilakukan dengan melatih petugas first line dengan peralatan sebenarnya atau dengan simulasi yang akan digunakan dalam pekerjaan. Variabel terikat adalah kompetensi dan kinerja petugas. Kompetensi diobservasi dari pengetahuan, keterampilan dan sikap petugas first line yang diukur sebelum dan sesudah dilakukan pelatihan. Kinerja yaitu kemampuan melaksanakan kompetensi sebagai petugas first line BPBD Prov. Sulawesi Barat.

Pengumpulan data kompetensi dan kinerja diperoleh dengan menggunakan instrumen yang merujuk pada rancangan standar kompetensi kerja Badan Nasional Penanggulangan Bencana. Analisis data dilakukan dengan uji paired t-test untuk mengetahui kompetensi sebelum dan sesudah dilakukan pelatihan, dengan tingkat kepercayaan 95\% $(\alpha, 05)$. Data dianalisis secara komputerisasi.

\section{HASIL}

\section{Karakteristik responden}

Tabel 1 menunjukkan kategori umur petugas first line yang paling banyak adalah umur 26-38 tahun (57,6 $\%)$. Tingkat pendidikan paling banyak adalah diploma 3 (42,4\%). Masa kerja di BPBD Prov. Sulawesi Barat 
paling banyak adalah 3-7 tahun (48,5\%). Pengalaman dalam penanganan bencana paling banyak $<3$ tahun $(48,5 \%)$.

Tabel 1. Karakteristik petugas first line badan penanggulangan bencana daerah Provinsi Sulawesi Barat

\begin{tabular}{lcc}
\hline \multicolumn{1}{c}{ Variabel } & $\mathbf{n = 3 3}$ & $\%$ \\
\hline Umur & 7 & 21.2 \\
$>38$ tahun & 19 & 57.6 \\
26-38 tahun & 7 & 21.2 \\
$<26$ tahun & & \\
\hline Tingkat pendidikan & 12 & 36.4 \\
SMA & 14 & 42.4 \\
Diploma 3 & 7 & 21.2 \\
Sarjana & & \\
\hline Masa kerja & 9 & 27.3 \\
$>7$ tahun & 16 & 48.5 \\
3-7 tahun & 8 & 24.2 \\
$<3$ tahun & & \\
\hline Pengalaman & penanganan & 21.2 \\
bencana & 10 & 30.3 \\
$>$ 5 tahun & 16 & 48.5 \\
3-5 tahun & & \\
$<3$ tahun & & \\
\hline
\end{tabular}

\section{Kompetensi}

Tabel 2. Kompetensi petugas first line Badan Penanggulangan Bencana Daerah Provinsi Sulawesi Barat

\begin{tabular}{lccc}
\hline Variabel & & Rerata \pm SD & p \\
\hline Kompetensi & sebelum & $36,52 \pm 6,31$ & 0,0005 \\
dilakukan pelatihan & & & \\
$\begin{array}{l}\text { Kompetensi } \\
\text { dilakukan pelatihan }\end{array}$ & sesudah & $61,70 \pm 6,94$ & \\
\hline
\end{tabular}

Tabel 2 menunjukkan rerata dan standar deviasi kompetensi sebelum dan sesudah dilakukan pelatihan. Uji paired t-test menunjukkan peningkatan kompetensi petugas first line Badan Penanggulangan Bencana Daerah Provinsi Sulawesi Barat setelah dilakukan pelatihan dengan nilai $p 0,005$.

\section{Kineria}

Tabel 3 menunjukkan rerata dan standar deviasi kinerja sebelum dan sesudah dilakukannya pelatihan. Uji paired t-test menunjukkan peningkatan kinerja petugas first line Badan Penanggulangan Bencana Daerah Provinsi Sulawesi Barat setelah dilakukan pelatihan dengan nilai $p=0,0005$.

Tabel 3. Kinerja petugas first line Badan Penanggulangan Bencana Daerah Provinsi Sulawesi Barat

\begin{tabular}{lccc}
\hline Variabel & & Rerata \pm SD & p \\
\hline $\begin{array}{l}\text { Kinerja sebelum dilakukan } \\
\text { pelatihan }\end{array}$ & $36,73 \pm 6,20$ & 0,0005 \\
$\begin{array}{l}\text { Kinerja sesudah dilakukan } \\
\text { pelatihan }\end{array}$ & $60,15 \pm 7,31$ & \\
\hline
\end{tabular}

\section{PEMBAHASAN}

Hasil penelitian ini memperlihatkan bahwa terdapat pengaruh yang signifikan dari pelatihan terhadap kompetensi dan kinerja petugas first line. Hal ini sesuai dengan hasil penelitian yang menyatakan bahwa pelatihan mempengaruhi kompetensi dan kinerja karyawan. Pelatihan yang diberikan kepada karyawan ternyata dapat mendorong karyawan bekerja lebih giat sehingga meningkatkan kinerja setiap karyawan. $^{9}$

Penelitian yang pernah dilakukan menunjukkan adanya pengaruh metode pelatihan On The Job Training dan materi pelatihan terhadap kompetensi karyawan; ada pengaruh metode pelatihan On The Job Training dan materi pelatihan terhadap kinerja karyawan, sehingga disimpulkan bahwa kompetensi karyawan berpengaruh secara signifikan terhadap kinerja karyawan. $^{10,11}$

Ada tiga komponen utama pembentukan kompetensi, yaitu pengetahuan yang dimiliki seseorang, keterampilan, dan perilaku individu, yang mana ketiga komponen tersebut dipengaruhi oleh konsep diri, sifat bawaan diri (trait), dan motif. Kinerja merupakan suatu fungsi dari motivasi dan kemampuan, untuk menyelesaikan tugas atau pekerjaan seseorang sepatutnya memiliki derajat kesediaan dan tingkat kemampuan tertentu. ${ }^{12}$

Beberapa penelitian juga menunjukkan hasil yang sama tentang pengaruh pendidikan pelatihan dan kompetensi secara bersama-sama berpengaruh 
signifikan terhadap kinerja. Hasil ini juga secara signifikan bermakna diberbagai area penelitian seperti karyawan PT. Frisian Plag ${ }^{13}$; PT. Gatra Mapan ${ }^{10}$; PT Perkebunan Nusantara $\mathrm{X}^{11}$; PT Bank Riau ${ }^{14}$; Eco Green Park ${ }^{15}$; PT PLN ${ }^{9}$, maka dapat disimpulkan pendidikan pelatihan dan kompetensi secara bersamasama berpengaruh signifikan terhadap kinerja.

Pelatihan dan pengembangan dapat memberi manfaat untuk organisasi dan pegawai itu sendiri karena dapat memperbaiki penguasaan berbagai keterampilan dan teknik pelaksanaan kerja secara terinci dan rutin. Pelatihan merupakan suatu proses pendidikan, yang tujuannya untuk meningkatkan kompetensi dan keterampilan khusus seseorang atau sekelompok orang yang menduduki suatu jabatan atau tugas tertentu. Hasil penelitian ini sejalan dengan pendapat bahwa pelatihan merupakan setiap aktivitas formal dan informal yang memberikan kontribusi terhadap perbaikan dan peningkatan tingkat pengetahuan, keterampilan dan sikap karyawan. Pelatihan sendiri pada dasarnya bertujuan untuk meningkatkan pengetahuan, keterampilan, dan sikap karyawan serta meningkatkan kualitas dan produktivitas organisasi secara keseluruhan, dengan kata lain tujuan pelatihan adalah meningkatkan kinerja dan pada gilirannya akan meningkatkan daya saing. ${ }^{16}$

Berdasarkan uraian di atas dapat disimpulkan bahwa kompetensi adalah kemampuan dan kemauan untuk melakukan sebuah tugas dengan kinerja yang efektif. Semakin baik pendidikan dan pelatihan yang diterima oleh karyawan maka akan semakin meningkat pula kompetensi yang dimiliki dan akan semakin meningkat pula kineja yang akan ditunjukkan oleh karyawan

\section{SIMPULAN}

Pelatihan pertolongan pertama pada korban bencana meningkatkan kompetensi dan kinerja petugas first line Badan Penanggulangan Bencana Daerah Provinsi Sulawesi Barat. Disarankan untuk mencapai optimalisasi kinerja petugas first line, dilaksanakannya simulasi atau latihan bersama dan seminar penanggulangan bencana terpadu setiap semester.

\section{DAFTAR PUSTAKA}

1. Nugroho S. Refleksi akhir tahun 2016: Pengarusutamaan budaya sadar bencana perlu ditingkatkan. Badan Nasional Penanggulangan Bencana. 2016 [diunduh 2 Januari 2017]. Tersedia dari: URL: HYPERLINK http://www.bnpb.go.id/

2. Majid D. Peningkatan kesiapsiagaan menghadapi ancaman bencana banjir dan longsor di Provinsi Sulawesi Barat Mamuju. Badan Nasional Penanggulangan Bencana. 2014 [2 Januari 2017 ]. Tersedia dari URL: HYPERLINK http://pusdiklat. bnpb.go.id/

3. Yohanis Y, Malino D, Pakiding F. Laporan Status lingkungan hidup daerah Provinsi Sulawesi Barat tahun 2015. 2015.

4. Yohanis, Malino D, Fakiding P. Status Lingkungan hidup daerah Provinsi Sulawesi Barat tahun 2015. Mamuju; 2015.

5. Kemendiknas. Kurikulum inti Pendidikan tinggi. Indonesia; 2002.

6. Menakestrans. Tata Cara penentuan standar kompetensi kerja nasional Indonesia. Indonesia. 2007.

7. Hadi F. Rancangan Standar kompetensi kerja nasional Indonesia Sektor penanggulangan bencana. Jakarta: BNPB; 2012. 455-62.

8. Mangkunegara AP. Manajemen Sumber daya manusia perusahaan. Bandung: Remaja Rosdakarya; 2006.

9. Aditya R, Utami HN, Ruhaya I. Pengaruh pelatihan terhadap kompetensi dan kinerja karyawan (studi pada karyawan PT . PLN (Persero) distribusi Jawa Timur Area Malang). J Adm Bisnis. 2015;27(2):16.

10. Ardiansyah A, Al Musadieq M, Ruhana I. Pengaruh pelatihan terhadap kompetensi dan kinerja (studi pada karyawan departemen research and development PT. Gatra Mapan Malang). J Adm Bisnis. 2014;9(1):1-8.

11. Febriyanti AR, Utami HN, Hakam MS. Pengaruh Pelatihan terhadap kompetensi dan kinerja karyawan (studi pada PT. Perkebunan Nusantara $X$ (Persero) PG. Lestari Nganjuk). J Adm Bisnis. 2013;1(2):158-67. 
12. Rivai V. Manajemen sumber daya manusia untuk perusahaan. Jakarta: PT. Raja Grafindo Persada; 2004.

13.Winanti MB. Pengaruh kompetensi terhadap kinerja karyawan (survei pada PT. Frisian Flag Indonesia Wilayah Jawa Barat). Maj IIm UNIKOM. 2003;7(2):249-67.

14.Hendriani S, Efni Y, Fitriani A. Pengaruh pendidikan dan pelatihan, kompetensi terhadap kinerja karyawan PT. Bank Riau Kepri Kantor Pusat Pekanbaru. Pekbis J. 2013;5(2):133-44.

15. Saraswati AB, Hamid D, Topowijono T. Pengaruh pelatihan terhadap kompetensi karyawan dan kualitas pelayanan (studi pada Eco Green Park, Batu). J Adm Bisnis. 2015;23(2):1-9.

16. Sudrajat AS. Seri khazanah kearifan. Jakarta: Erlangga; 2006. 